\title{
Człowiek w horyzoncie dziejów i autentyczności bycia Studia z filozofii Jana Patočki
}


PRACE NAUKOWE

$\because 4$.

UNIWERSYTETU

ŚLĄSKIEGO

W KATOWICACH

NR 3507 
Dariusz Bęben

\section{Człowiek}

\section{w horyzoncie dziejów i autentyczności bycia}

Studia z filozofii Jana Patočki 
Redaktor serii: Filozofia

Dariusz Kubok

Recenzent

Jan Zouhar

Praca powstała w wyniku realizacji projektu badawczego

o numerze 2011/03/B/HS1/01700

finansowanego ze środków Narodowego Centrum Nauki

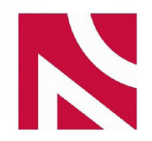

Redaktor: Małgorzata Pogłódek

Projektant okładki: Magdalena Starzyk

Redaktor techniczny: Barbara Arenhövel

Korektor: Katarzyna Kondracka

Łamanie: Bogusław Chruściński

Copyright (C) 2016 by

Wydawnictwo Uniwersytetu Śląskiego

Wszelkie prawa zastrzeżone

ISSN 0208-6336

ISBN 978-83-226-3031-0

(wersja drukowana)

ISBN 978-83-226-3032-7

(wersja elektroniczna)

Wydawca

Wydawnictwo Uniwersytetu Śląskiego

ul. Bankowa 12B, 40-007 Katowice www.wydawnictwo.us.edu.pl e-mail:wydawus@us.edu.pl

$\overline{\text { Wydanie I. Ark. druk. 14,25. Ark. wyd. 15,5. Papier }}$ Alto $80 \mathrm{~g}$, vol. 1.5 .

Druk i oprawa: „TOTEM.COM.PL Sp. z o.o.” Sp.K.

ul. Jacewska 89, 88-100 Inowrocław 


\section{Spis treści}

Wstęp

Rozdział 1

Człowiek w świecie idei . . . . . . . . . . . . . . . . . . . 15

Wprowadzenie . . . . . . . . . . . . . . 15

Zmierzch metafizyki . . . . . . . . . . . . . . . . . . . . 17

Czym jest metafizyka? . . . . . . . . . . . . . . . . . . . . . 19

Metafizyka nowożytna . . . . . . . . . . . . . . . . . . . 22

Metafizyka współczesna . . . . . . . . . . . . . . . . . . . . . . 29

Początek metafizyki . . . . . . . . . . . . . . . . . . . . . . 36

Doświadczenie wolności . . . . . . . . . . . . . . . . 40

Chorismos . . . . . . . . . . . . . . . . . 46

Dziejowość i wolność . . . . . . . . . . . . . . . . 48

Negatywny platonizm jako filozofia niemetafizyczna . . . . . . 50

Na zakończenie - życie w równowadze i życie w amplitudzie . . 53

Rozdział 2

Człowiek w dziejach . . . . . . . . . . . . . . . . . 55

Wprowadzenie . . . . . . . . . . . . . . . . 55

Człowiek jako istota dziejowa . . . . . . . . . . . . . . . . 57

Mit . . . . . . . . . . . . . . . . . . . . . . 62

Klasyfikacja dziejów . . . . . . . . . . . . . . . . . . . . . 65

Początek dziejów . . . . . . . . . . . . . . . . . . . . . . . . 67

Trzy podstawowe ruchy życia . . . . . . . . . . . . . . 71

Fenomenologia asubiektywna a dzieje . . . . . . . . . . 75

Sens dziejów . . . . . . . . . . . . . . . . . . . 77

Dzieje jako dzieje Europy . . . . . . . . . . . . . . . . . . . . 79

Troska o duszę . . . . . . . . . . . . . . . . . . . . 81

Koniec Europy . . . . . . . . . . . . . . . . . . . . 85

Heretycka filozofia dziejów . . . . . . . . . . . . . . . . 92

Na zakończenie - człowiek duchowy a intelektualista . . . . . 93 
Rozdział 3

Człowiek w narodzie . . . . . . . . . . . . . . . . . 97

Wprowadzenie . . . . . . . . . . . . . . . 97

O kwestii czeskiej . . . . . . . . . . . . . . . . . . . . . 99

O małym narodzie w centrum Europy . . . . . . . . . . . 101

Dwa pojęcia narodu . . . . . . . . . . . . . . . . . . . . 108

Synteza Palackiego . . . . . . . . . . . . . . . . . 114

Masaryka myślenie o dziejach . . . . . . . . . . . . . . . 120

Karta 77 jako problem filozoficzny . . . . . . . . . . . . . 130

Filozofia czeskich dziejów . . . . . . . . . . . . . . 139

Na zakończenie - życie w idei a życie w ideologii . . . . . . . 143

Rozdział 4

Człowiek w świecie filozofii i polityki . . . . . . . . . . . 147

Wprowadzenie . . . . . . . . . . . . . 147

Człowiek w świecie filozofów . . . . . . . . . . . . . 150

Człowiek w świecie polityki . . . . . . . . . . . . . . . . 173

Na zakończenie - czy istnieje kanon życia filozoficznego? . . . 194

Zakończenie . . . . . . . . . . . . . . . . 197

Bibliografia . . . . . . . . . . . . . . . . 203

Bibliografia podmiotowa . . . . . . . . . . . . . 203

Bibliografia przedmiotowa . . . . . . . . . . . . . . 208

Indeks nazw osobowych . . . . . . . . . . . . . . . . . . . . 219

Summary . . . . . . . . . . . . . . . . . . 225

Zusammenfassung . . . . . . . . . . . . . . . . . . . . 227 


\section{Wstęp}

W długich rozmowach, które dusza prowadzi sama z sobą, odpowiedzi położone są przed pytaniami. Odpowiedzi są wieczne, pytania czekają na swój czas [...]. We wszystkich tych pytaniach dusza jest sama ${ }^{1}$.

Już niemal obowiązkiem każdej pracy dotyczącej filozofii Jana Patočki jest przywołanie opinii Romana Jakobsona. Ten wybitny rosyjski językoznawca, związany w latach międzywojennych z Praską Szkołą Lingwistyczną, stwierdził, że Czesi mają trzech myślicieli o uniwersalnym znaczeniu: Jana Amosa Komeńskiego, Tomáša G. Masaryka oraz właśnie Jana Patočkę 2 . Pierwszy z nich jest jednym z największych europejskich nauczycieli. Masarykowi z kolei, jak nikomu przed nim w czasach nowożytnych, udało się utworzyć państwo demokratyczne. Zrealizował on platońskie marzenie o filozofie na tronie. Na czym zaś polega doniosłość filozofii Patočki? Trudno o jednoznaczną odpowiedź.

Na pewno śmierć Patočki - od razu narzuca się porównanie z Sokratesem - przyczyniła się do jego sławy, która przekroczyła uznanie, jakim zazwyczaj cieszą się w swych krajach filozofowie. Patočka jest już czeskim mitem, obiektem kultu dotąd zarezerwowanego jedynie dla Masaryka i Komeńskiego. Ten skromny filozof stał się symbolem narodowym, wzorem filozofa résistance. Teksty Patočki, których publikowanie $\mathrm{w}$ latach panowania socjalizmu często było zakazane, dziś ukazują się $w$ wielotomowych wydaniach krytycz-

${ }^{1}$ O. Březina: Hudba pramenů a jiné eseje. Praha 1976, s. 9.

${ }^{2}$ Por. R. Jakobson: Postowie. W: J. Patočka: Kim sa Czesi?. Przeł. M. Zybura. Wiedeń 1991, s. 103. 
nych $^{3}$. Uczniowie Patočki, którzy potajemnie zbierali się $\mathrm{w}$ jego domu na wykładach, dziś jeżdżą po świecie i upowszechniają dzieło mistrza. Sława filozofa już dawno przekroczyła granice Wełtawy. Naturalnie, cała ta hagiografia ma także swe złe strony ${ }^{4}$. Przede wszystkim dramatyczna śmierć i wydarzenia polityczne związane z Kartą 77 przesłaniają jego dorobek filozoficzny. Co prawda, nie można - i tu znowu warto przywołać Sokratesa - zupełnie oddzielić tych spraw, niemniej jednak na proste pytanie: czy filozofia Patočki broni się bez jego politycznego zaangażowania?, pada odpowiedź twierdząca. Patočka nie był męczennikiem, sumieniem narodu. Po prostu zrobił to, co powinien uczynić filozof.

Czeski filozof to myśliciel niezwykle wszechstronny, o czym świadczą jego rozprawy dotyczące historii filozofii, sztuki czy historii nauki. Jeden z jego uczniów pisał: „Patočka był człowiekiem duchowym o różnorodnych zainteresowaniach i zdolnościach. Jego szeroki horyzont obejmował sztukę, literaturę, teatr, religię, komeniologię, historię powszechną, historię nauk, politykę, języki klasyczne, zachodnie i słowiańskie [...] cały jednak pochłonięty był filozofią. Była ona dla niego nie tylko powołaniem i misją, lecz miał do niej także stosunek porównywalny do stanu, jaki czasami miewają ludzie wobec swego hobby, to znaczy stosunek graniczący wręcz z obsesją. Przez czterdzieści lat, odkąd zajmuję się filozofią, miałem możliwość poznania licznego grona osób poświęcających się tej dyscyplinie, w tym także wielu o światowej renomie, nigdy jednak nie spotkałem się z człowiekiem, który był tak oddany filozofii jak Patočka" ${ }^{5}$.

Za życia opublikował jednak niewiele. W zasadzie tylko dwie książki: Świat naturalny jako problem filozoficzny oraz Aristoteles, jeho předchůdci a dědicové. Pozostawił po sobie wszak dorobek ogromny, liczący ponad dziesięć tysięcy stron maszynopisu. Spektrum jego zainteresowań i badań jest tak szerokie, że przełożyło się również na trudność w systematycznym i spójnym przygotowaniu oraz wydaniu dzieł zebranych ${ }^{6}$. Już samo opracowanie, zredagowanie, a następnie wydanie dzieł stanowi trudną pracę filozoficzną, która nie

${ }^{3}$ Por. E. Kohák: Domova a dálava. Kulturní totožnost a obecne lidství v českém myšlení. Praha 2009, s. 247.

${ }^{4}$ Por. P. Fischer: Co ještě zůstává z mýtu filozofa Jana Patočki?. „Hospodářské noviny" z 13.03.2007, s. 11.

${ }^{5}$ I. Tretera: Několik vzpominek in margine Patočkových Heideggerovských seminář́u. „Studia Comeniana et Historica” 1994, č. 52, s. 53.

${ }^{6}$ Por. I. Chvatík, P. Kouba, M. Petříček: Struktura "Sebraných spisü" Jana Patočky jako interpretačni problém. „Filosofický časopis” 1991, č. 3, s. 400. 
została jeszcze zakończona. Badacze twórczości Patočki stają przed problemem wyznaczenia kluczowego punktu, wokół którego ogniskuje się jego filozofia. Można powiedzieć, że wewnętrzna struktura dzieła Czecha przypomina bardziej Heideggerowską „drogę" niż Husserlowską „ideę". Trudno jednoznacznie wskazać centrum, które określałoby ruch filozofowania Patočki. Można o nim powiedzieć, że to typowy Philosoph ohne Mitte. W jego rozważaniach wiele jest kluczowych i scalających tematów, takich jak: świat naturalny, filozofia dziejów, fenomenologia asubiektywna, troska o duszę 7 . Uważam jednak, że różnorodność perspektyw, wzajemnie przenikających się i krzyżujących się motywów wcale nie zniekształca ośrodka jego myślenia, którym jest walka o autentyczne bycie człowieka w świecie.

Patočka interesuje się człowiekiem, który staje do walki o swą duszę (który z niekonfesyjnych filozofów najnowszych mówił w ogóle o duszy?), co przejawia się w odrzucaniu tego, co oczywiste, tego, co absolutne, tego, co pozaświatowe, tego, co pewne. Patrząc na to z innej perspektywy, neguje Kartezjański dualizm, intelektualizm, prymat technologii nad duchem, globalizację, możliwość zapanowania nad dziejami. Człowiek nie żyje w świecie jako obojętny obserwator. Jego egzystencja $w$ świecie jest wszak tym, co wręcz zmusza go do podejmowania decyzji, przedsięwzięcia ryzyka. Patočka stwierdzał:

Filozofia jest radosna rezygnacją; poznaje absolut, ale nigdy absolutnie. Kto to poznał, nie może nigdy stać się ani dogmatykiem, ani sceptykiem ${ }^{8}$.

Zdaniem niniejszej rozprawy jest ukazanie głównego celu Patočki, czyli rozjaśnienie autentycznej egzystencji człowieka9. Zdaniem

7 Por. J. Moural: The Question of the Core of Patočka's Work: Phenomenology, History of Philosophy, and Philosophy of History. "Report of the CTS” 1999. Report of the CTS 99-0; I. Srubar: Asubjektive Phänomenologie, Lebenswelt und Humanismus. Zur Verortung des Denkens Jan Patočkas zwischen Husserl und Heidegger. „Mesotes" 1991, no 1, s. 5-13; F. Karfík: Die Odyssee des endliche gewordenen Absoluten. Patočkas systematische Versuche zwischen 1936 und 1964. In: Idem: Unendlichwerden durch die Endlichkeit. Eine Lektüre der Philosophie Jan Patočka. Würzburg 2008, s. 32-54.

8 J. Patočka: Kapitoly ze současné filosofie. V: Idem: Péče o duší. Sv. 1. Připr. I. Chvatík, P. Kouba. Praha 1996, s. 96.

9 J. Patočka: Martin Heidegger - myslitel lidskosti. Improvizovaná úvaha po zprávĕ o Heideggerovĕ smrti. „Filosofický časopis” 1995, č. 1, s. 4. 
czeskiego filozofa, człowiek, który chce żyć w prawdzie, nie może sobie pozwolić na poszukiwania wyłącznie na nizinach egzystencji, nie może pozwolić, aby uśpiła go spokojna harmonia codzienności; musi otworzyć się na to, co niepokojące oraz tajemnicze, czyli na to, od czego zwykle życie odwraca się, by przejść od porządku dnia do tajemnicy nocy.

Praca składa się z czterech rozdziałów. Trzy kolejne omawiają następujące tematy: metafizyka, dzieje oraz naród. Rozdział ostatni poświęcony jest biografii czeskiego filozofa.

Jan Patočka krytycznie odnosił się do historii metafizyki klasycznej (od Platona do Husserla), uważając, że dążyła ona do tego, co pewne, obiektywne, a w końcu - absolutne i wieczne. Przeciwstawiał temu Sokratejską niepewność i problematyczność. Koncepcja Patočki szczególnie uwidoczniła się $\mathrm{w}$ interpretacji Platona teorii idei. Praski filozof zaprezentował Sokratejską wersję Platońskiej teorii idei, próbując scharakteryzować ją z pozycji doświadczenia ludzkiej wolności oraz z perspektywy dziejów ludzkiej egzystencji. Dzięki pomocy Sokratesa, Platona, Hegla, Husserla oraz Heideggera ukonstytuował nową formę wiedzy o absolutnym transcendowaniu, w którym zachodziła szczególna relacja życia człowieka do całości, w tym prymarne odniesienie do niebytu. Patočka podkreślał motyw negatywności jako immanentnej cechy ludzkiej wolności.

Podejście Patočki do filozofii dziejów jest szczególne, by nie powiedzieć: heretyckie. Wyjątkowość ta wynika z ustalenia, czym są dzieje i dziejowość. Można powiedzieć, że koncepcja praskiego filozofa wykraczała poza ramy klasycznie rozumianej filozofii dziejów (Herder, Hegel). Patočka nie traktował jej jako filozoficznego namysłu nad historią, tym bardziej nie miał na myśli żadnych rozważań historiograficznych: filozofia dziejów nie jest interpretacją sensu tego, co się wydarzyło. Zdaniem Patočki, dzieje od zawsze oznaczają dzieje człowieka.

Kolejnym ważnym tematem podjętym $\mathrm{w}$ rozprawie, jest zagadnienie dziejów Europy. Rozważania te były ściśle związane z filozofią dziejów. Europę traktował praski myśliciel nie jako pojęcie geograficzne ani polityczne, lecz przede wszystkim rozpatrywał ją w kategorii konceptu, który spoczywa na duchowych podstawach. Europa to pojęcie filozoficzne. Na pytanie o to, czym jest w Europa, odpowiadał, opisując i rozjaśniając jej dzieje oraz siły, które nią rządzą. W swych rozważaniach Patočka koncentrował się na jej powstaniu (stawiając kwestie typu: jak Europa stała się Europą?) oraz na tym, co nastąpiło później, a co czeski filozof określił mianem epoki poeuropejskiej (dlaczego upadła Europa?). Nie bez znaczenia 
pozostawało również to, co rozpościerało się pomiędzy narodzinami a śmiercią, czyli jak przebiegały duchowe losy Europy. Podstawą dziedzictwa europejskiego, czyli tym, co stanowiło początek historii europejskiej, była troska o duszę.

Jan Patočka przy wielu okazjach podkreślał, że Czechy nie są ziemią bogatą w tradycję filozoficzną. Czechy to mały naród europejski, skrywający się za niedostępnym językiem, trudną historią i nieznaną kulturą. Nie było tam zbyt wielu samodzielnych oraz twórczych myślicieli, lecz zdarza się i tak, że w duchowych dziejach Europy również małe państwa mogą nie tylko odzwierciedlać, lecz także współkształtować uniwersalne i fundamentalne wydarzenia duchowe. W rezultacie historia małego narodu staje się częścią wielkiej historii i kultury europejskiej. Zdarzyło się tak w przypadku czeskiej muzyki, którą współcześnie reprezentowali Bedřich Smetana, Antonín Dvořák, Leoš Janáček; czeskiej literatury, w osobach między innymi Jaroslava Haška, Bohumila Hrabala, Milana Kundery czy Jaroslava Seiferta, a także czeskiej polityki w wydaniu Tomáša Garrigue Masaryka, Alexandra Dubčeka czy Václava Havla.

W dyskusji dotyczącej sensu czeskich dziejów nie mogło zabraknąć głosu Patočki. Po pierwsze, odnosił się do historii samego sporu, polemizując z poglądami Jungmanna, Bolzana, Palackiego, przede wszystkim zaś Masaryka. Po drugie, można w tym kontekście nieco szerzej spojrzeć na samą Patočki koncepcję filozofii dziejów - pod kątem jej narodowego odniesienia czy mówiąc inaczej: przez pryzmat filozoficznej i politycznej odpowiedzialności jednostki w życiu społeczno-politycznym.

Trzeba powiedzieć jeszcze kilka zdań na temat Patočki jako historyka filozofii. Filozofowanie autora Esejów heretyckich... to nieustanna dyskusja z tradycją filozoficzną. Na pierwszy rzut oka może to przypominać Heideggerowskie współfilozofowanie. Patočka uważał historię filozofii za wstęp do filozofii, ponieważ najlepiej wyjaśniała ona powstanie filozofii ${ }^{10}$. Stwierdzał:

W filozofii nie chodzi mianowicie o nowe myśli, lecz o pogłębienie i oswojenie myśli, którym genialni myśliciele otworzyli drogę. Kto to zrozumie, może się z czasem stać i twórczym filozofem ${ }^{11}$.

Patočka w jednym ze swych szkiców napisał, że jego filozoficzne życie nie zrodziło żadnej godnej uwagi nowej myśli, lecz poruszało

10 Por. V. Leško: Filozofia dejín filozofie. Prešov 2004.

${ }^{11}$ J. Patočka: Mládi a filosofie. V: Idem: Péče o duši. Sv. 1..., s. 125. 
się między ważnymi kierunkami i osobami ${ }^{12}$. W pewnym sensie miał rację, nie stworzył bowiem nowego kierunku, jak uczynili to Henri Bergson, Edmund Husserl, Martin Heidegger czy Jean-Paul Sartre. Bardzo często słyszy się, że filozofia Patočki lokuje się gdzieś pomiędzy fenomenologią transcendentalną Husserla a ontologią egzystencjalną Heideggera. Uważam, że taki sposób stawiania sprawy jest niesprawiedliwy dla Patočki, ponieważ jego myśl otwiera - choć faktycznie iurare in verba magistri - zupełnie nową perspektywę filozofii fenomenologicznej.

Rozprawę zamyka rozdział czwarty, poświęcony drodze filozoficznej i politycznej czeskiego filozofa. Filozofii Patočki bowiem nie sposób oddzielić od jego biografii ${ }^{13}$. Życie filozofa jest czymś szczególnym. Już od czasów Sokratesa wiemy, że lepiej bezprawnie cierpieć, niż bezprawnie grzeszyć. Ponieważ filozofia Patočki ściśle wiąże się z dziejami życia praskiego filozofa, to ostatni fragment książki przedstawia jego biografię intelektualną. Składa się ona z dwóch części: pierwsza opisuje filozofów, którzy wpłynęli na rozwój jego poglądów, poczynając od filozofii greckiej, przez Husserla i Heideggera, na Komeńskim kończąc. Cała ta bogata inspiracja pokazuje, że w filozoficznym dorobku Patočki na pierwszy plan wysuwa się jedność historii filozofii i filozofii dziejów. Część druga dotyczy filozoficznego (ale także osobistego) udziału Jana Patočki w wydarzeniach politycznych, jakie zaszły w Czechosłowacji. Był on naocznym świadkiem tragicznych wydarzeń, które wstrząsnęły jego państwem: z zaniepokojeniem śledził układ monachijski w 1938 roku, obserwował przejęcie władzy przez komunistów w 1948 roku, sympatyzował z Praską Wiosną w 1968 roku, wreszcie wziął czynny udział w deklaracji Karty 77. Na jego oczach powstawała i kształtowała swój młody ustrój Pierwsza Republika Czechosłowacka.

Szczególne podziękowania kieruję do Żony, dr Marty Ples-Bęben, za wsparcie na każdym etapie powstawania książki. Dziękuję także wnikliwym czytelnikom manuskryptu: Doktorom Marcinowi Furmanowi oraz Łukaszowi Rąbowi. Pracę nad książką znacząco ułatwił mi pobyt w praskim Archiwum Jana Patočki. Za filozoficzną gościnę w jego progach dziękuję Doktorowi Janowi Freiowi. Nie

12 Por. J. Patočka: Přednáška pro redaktory čs. rozhlasu (22. II. 1967). V: Idem: Češi. Sv. 1. Připr. K. Palek, I. Chvatík. Praha 2006, s. 806.

${ }^{13}$ Por. J. Novák: Selected Bibliography of Jan Patočka's Writings. „Kosmas: Journal of Czechoslavak and Central European Studies" 1986, vol. 5, no 2, s. 115-139. 
mogę tu także nie wspomnieć o słowackim filozofie Profesorze Vladimírze Lešce (oraz o Jego koszyckich uczniach), z którego strony zawsze mogłem liczyć na cenne i pomocne uwagi. Składam też wyrazy wdzięczności moim Nauczycielom i Mistrzom - Profesorowi Czesławowi Głombikowi oraz Profesorowi Andrzejowi J. Norasowi - dziękuję Im za inspirację, dyskusje i przychylność. 


\section{Indeks nazw osobowych}

Abrams Erica 16, 185, 208, 211

Anaksagoras 22

Anders Jarosław 100, 208

Andreanský Eugen 37, 113, 208

Arendt Hannah 73, 208

Arnason Johann P. 20, 208, 210

Arystoteles 21, 22, 30, 33, 37-40, 71, 72, 81, 147, 157, 161, 162, 168, 169, 173, 189, 203, 208, 212

Ash Timothy Garton 100, 208

Aubenque Pierre 37, 208

Bacon Francis 24, 26, 87

Baluch Jacek 99, 100, 135, 120, 205, 212

Baran Bogdan 21, 42, 58, 61, 212, 216

Barbaras Renaud 16, 48, 208, 210

Barraclough Geoffrey 86, 87, 209

Batowski Henryki 119, 214

Beauvoir Simone de 155

Becker Oskar 65, 209

Bednář Miroslav 52, 125, 126, 136, 209

Bélohradský Václav 136, 192, 209

Benda Václav 137-138, 209

Bendlová Peluska 155, 210

Beneš Edvard 104, 107, 108, 150, 175, 205, 212

Benoist Jocelyn 16, 209

Benyovszky Ladislav 82, 210

Bergson Henri 12, 156, 159

Bęben Dariusz 22, 69, 108, 120, 123, 208, 210, 215, 217, 218
Biemel Walter 150, 180, 209

Bieńczyk Marek 102, 214

Binder Thomas 164, 209

Bismarck Otto von 86, 127

Blandzi Seweryn 5, 39, 54, 212

Blaschek-Hahn Helga 173, 213

Blecha Ivan 39, 55, 81, 109, 150, 154, 177, 209

Bodnár Ján 72, 207

Bolton Jonathan 183, 209

Bolzano Bernard 98, 103, 108-109, 112-115，142, 172，203，204，208, 209

Boreš Jiři 190, 210

Böll Heinrich 183

Brabec Jiři 100

Brehier Émile 155

Brentano Franz 164, 165, 209

Breżniew Leonid 182

Brock Werner 162

Brod Max 165

Brunschvicg Léon 156

Bruzina Ronald 163, 210

Březina Otokar 7, 210

Čáda František 155

Cairns Dorion 163, 210

Cajthaml Martin 83, 210

Campbell Robert 157, 176, 208

Čapek Jakub 210

Čapek Karel 150

Čápová Anna Klara 175, 211

Cauly Olivier 16, 210

Ceaussescu Nicolae 182. 
Černý Bohumil 171

Černý Václav 100, 102, 126, 127, 175, 183, 210

Chvatík Ivan $16,17,25,27,29,40,43$, $48,57,64,69,82,92,93,98,103,115$, $129,147,148,151,155,160,161,164$, 185, 197, 202-208, 210, 211, 217

Čisař Čestmír 210

Císařovská Blanka 139, 188, 190, 215217

Comte Auguste $18,25,62,124-126$

Crosland Anthony 191

Czcibor-Piotrowski Andrzej 40, 82, 204

Czernikow Olga 98, 182, 213

Czyżewski Dmitrij 165, 173, 213

David Zdenek V. 110, 210

Demokryt 22, 40, 81, 82, 85, 168, 204

Denis Marcelle 155, 210

Derdowska Joanna 197, 213

Derrida Jacques $18,36,90,210$

Descartes René 21, 23, 24, 26, 30, 32, $34,35,50,51,88,148,160,155,166$, 189, 204

Dilthey Wilhelm 57, 210

Dobrovský Josef 108

Dorobiński Artur 33, 211

Dostojewski Fiodor 17, 123, 125, 190, 199, 202, 204, 211

Dratvová Albína 175, 211

Driesch Hans 152

Drop Agnieszka 90, 211

Droysen Johann Gustav 141

Drtina František 150, 155

Dubček Aleksander 108, 176, 177, 212,

Dubský Ivan 158, 159, 167, 181, 211

Durdík Josef 115

Dvořák Antonín 11

Dziadek Adam 36, 210

Einstein Albert 157

Eisenhower Dwight 180

Empedokles 22

Engelking Leszek 104, 212

Erdmann Benno 154

Evink Eddo 16, 211
Fink Eugen 39, 109, 159, 163, 166, 167, 200, 210, 211, 214

Fischer Ludvík Josef 100

Fischer Petr 8, 211

Frei Jan 12, 29, 160, 204, 206, 207

Fries Jakob Friedrich 114

Funke Gerhard 16, 211

Furman Marcin 12

Gabriel Jiří 122, 124, 125, 154, 173, 175, 212, 215, 218

Gadamer Hans-Georg 33, 37, 166, 167, 211

Gajda-Krynicka Janina 37, 211

Galileusz 26

Gałecki Jerzy 111, 118, 212.

Gatzemeier Matthias 28, 180, 209, 217

Gellner Ernest 192, 211

Gierek Edward 182

Gierulanka Danuta 31, 213

Gilson Étienne 155

Głombik Czesław 13

Godlewski Piotr 137, 189, 190, 209, 210, 218

Goethe Johann Wolfgang von 110, 125,127

Goll Jaroslav 100

Goněc Vladmír 167, 207

Gott Karel 186

Gottwald Klement 150, 175, 176, 186

Goszczyńska Joanna 139, 212

Grabiński Tomasz 193, 212

Grube Kurt 165

Hagedorn Ludger 92, 160, 172, 203, 211,217

Hájek Jiři 184, 185, 209, 211

Halík Tomáš 147, 211

Haller Rudolf 164, 209

Hanzal Josef 193, 212

Hartmann Max 157

Hartmann Mortiz 141

Hartmann Nicolai 148, 157, 206

Havel Václav 100, 104, 108, 132-136, 139, 143, 145, 184, 185, 190, 192, 193, 209, 210, 212 
Havelka Miloš 100, 217

Havlíček-Borovský Karel 114, 128, 139

Heczková Libuše 175, 211

Hegel Georg Wilhelm Friedrich 10, $18,21,23,25-30,33,36,50,56,57$, 60, 71, 86, 99, 102, 111, 115, 116, 119, $142,148,151,156,162,168,173,180$, 203, 217

Heidegger Martin $\quad 8-12,16-19,21,22$, $32-37,38,39,4245,47,49,50,58,60$, $61,72,73,76,89,90,96,109,132,147$, $149,151,156,157,161,162,163,167$, 178, 181, 195, 197, 200, 204, 205, 206, 211, 212, 215-217

Heinämaa Sara 16, 218

Heisenberg Werner Carl 157

Heitz Michael 164, 211

Hejdánek Ladislav 43, 134, 149, 209, 212

Heraklit 22, 39, 212

Herben Jan 100

Herder Johann Gottfried 10, 56, 110 $112,113-116,118,119,122,142,172$, $174,210,212$

Hermann Tomáš 152, 211

Hessen Sergiusz 167, 207

Heydrich Reinhard 150

Hilsner Leopold 170, 171

Hoffmann Ernst 46, 212

Holan Vladimír 15, 212

Holland Agnieszka 97, 133, 184, 212, 214

Holzbachová Ivana 122, 212

Hoppe Vladimír 151

Horák Petr 157, 176, 179, 208, 213

Hostynský Otakar 150.

Hrabal Bohumil 11, 100, 102, 137, 150, 209, 210, 214

Hroch Miroslav 101, 213

Hromádka Josef 100, 152, 153, 155, 156, 213.

Hrůzová Anežka 170

Humboldt Alexander von 156

Hume David 22, 126, 127

Hus Jan 102, 104, 105, 107, 118, 122, 125, 136, 140, 141, 156, 177, 193, 215

Husák Gustáv 150, 182, 186
Husserl Edmund 9, 10, 12, 15-17, 19, 22, 24, 30, 31-36, 38, 47, 50, 60, 71, $75,76,80,91,103,123,124,147,148$, 154-166, 172, 173, 177, 180, 195, 197, 204, 206, 207, 208-210, 213, 214, 217

Hvížd’ala Karel 132, 184, 212

Hyppolite Jean 173

Illg Jerzy 132, 133, 212

Ingarden Roman 15

Jaeger Werner 20, 157, 213

Jagodziński Sławomir Andrzej 55, 104, 108, 133, 184, 212, 217

Jakobson Roman 7, 213

Janáček Leoš 11

Jaspers Karl 94, 213

Jerzy z Podiebradów 141

Ješič Milovan 16, 37, 62, 208, 213, 216

Jirous Ivan 92, 182, 213

Józef II Habsburg 109

Judycki Stanisław 16, 213

Jungmann Josef 11, 98, 99, 108-110, 113, 114, 122, 204, 208, 213

Jusko Štefan $\quad 62,213$

Kafka Franz 176

Kaizl Josef 100

Kant Immanuel 16, 21, 34, 46, 50, 53, $115,132,142,147,148,190,195,210$, 216

Karásek Svatopluk 197, 213

Karfík Filip 103, 160, 162, 207, 213

Karlík Viktor 208

Karol I 170

Karol IV 102

Kepler Johannes 103

Kiełbasa Jan 43, 216

Killias Jarosław 129, 213

Klein Jacob 157, 161, 213

Klibansky Raymond 178, 179, 213

Klíma Ivan 183

Kłoczowski Jan Maria 149, 214

Kohák Erazim 121, 132, 144, 151, 213, 214

Köhler Wolfgang 157

Kohout Jaroslav 176, 183, 214 
Kohout Pavel 209

Kojève Alexandre 173

Kollař Ján 101, 119, 121, 214

Komárková Božena 140, 214

Komeński Jan Amos 7, 12, 102, 103, 122, 150, 155, 171-173, 205, 206

Kornecki Marek 69, 210

Kosík Karel 101, 107, 120, 178, 214, 218

Kouba Pavel 9, 17, 148, 40, 57, 129, 197, 204-207, 210, 214

Kovtun Jiří 170, 214

Koyré Alexandre 156

Kozák Jan Blahoslav 151-153, 154,

155, 164, 165, 205, 214

Kozłowski Władysław Mieczysław 127, 215

Kraus Oskar 165

Krejčí František 150, 151, 155, 214

Kroński Tadeusz 109, 203

Kroutvor Josef 100, 214

Kubalica Tomasz 108, 215

Kučera Martin 122, 214

Kundera Milan 97, 100, 102, 209, 210, 214

Kvačala Jan 171

Kwapis Robert 176, 214

Laignel-Lavastine Alexandra 149, 214

Lalande André 150, 159

Landgrebe Ludwig 16, 134, 159, 160, 164-166, 180, 211

Lau Yin Kwok 64, 214

Leghissa Giovanni 148, 210

Leibniz Wilhelm Gottfried 21, 33

Leśniak Kazimierz 71, 208

Leško Vladimír 11, 16, 37, 62, 109, 148, 208, 209, 213, 214, 216

Leštinová Zuzana 175, 211

Lévinas Emmanuel 149

Liebert Arthur 166

Loewenstein Bedřich 171, 192, 214, 215

Loužil Jaromír 113, 209

Ludwig Emil (właśc. Emil Cohn) 149, 215

Łaciak Piotr 121, 123, 217, 218
Łagodzka Anna 73, 208

Łosski Władimir 159

Mácha Hynek Karel 43, 207

Machovec Martin 182, 197, 213

Machovec Milan 98, 115, 141, 177, 182, 189, 190, 215, 216

Macura Vladmír 108, 215

Malebranche Nicolas 155

Malínská Jana 149, 215

Marciszuk Piotr 33, 178, 200, 205, 211

Mareš František 151

Margański Jerzy 36, 210

Markoš Anton 152, 211

Marks Karl 18, 28, 29, 56, 60, 116, 178, 192

Marszałek Robert $\quad 49,212$

Marzęcki Józef 19, 213, 217

Masaryk Tomáš Garrigue 2, 62, 98$101,104,107,113,114,118,120-129$, 132, 136, 138-140, 143, 147, 149-152, 154, 158, 166, 169-171，173，177， 190, 194, 204, 206, 209, 210, 211, 214, 215

Meinhardt Helmut 46, 215

Merleau-Ponty Maurice 155

Meyerson Emil 156

Michálek Jiří 16, 93, 204

Michalski Krzysztof 18, 163, 203, 205, 212

Mikołaj z Kuzy 172

Milton John 110

Miłosz Czesław 149, 214

Mordka Artur 52, 156, 157, 206, 208, 216

Morscher Edgar 108, 215

Mukařovský Jan 165

Nellen Klaus 18, 19, 47, 184, 203, 204

Nĕmec Jiř́i 18, 19, 47, 183, 184, 203, 204

Nenon Thomas 213

Nessler Bernhard 164, 211

Newton Isaac 26

Nietzsche Friedrich 17, 18, 50, 78, 123, 128, 204, 215

Noras Andrzej J. 13 
Novák Josef 12, 169, 217

Novotný Antonin 179

Novotný Karel 47, 92, 215

Nový Lubomir 122, 124, 212, 215

Opat Jaroslav 126, 215

Orłoś Zofia Terasa 103, 215

Ott Hugo 162, 215

Palek Karel 12, 25, 98, 103, 151, 161, 202, 203, 204-208

Pańko Grażyna 101, 213

Patočka Františka 151

Patočka Josef 150

Palacký František 99, 101, 113, $114-$ $122,124,125,128,140,145,169$, 205-206, 215

Palouš Martin 168, 215

Palouš Radim 171, 191, 215, 216

Parmenides 22, 33, 37, 39, 209, 216

Pascal Blaise 155

Patyna Wojciech 178, 200, 205, 211

Pauza Miroslav 216

Pavlincová Helena 112, 124, 225, 218

Pelikán Ferdinand 151

Pekař Josef 100, 122, 214

Petř́íček Miroslav 8, 62, 210, 216

Petsch Danuta 86, 209

Pignet Janine 136, 183, 204

Pithart Petr 185, 216

Planck Max 157

Platon $7,10,16,17,20,21,23,26-$ $28,30,32,33,36-53,56,57,59,63$, $64,72,75,81,82,84,85,90,95$, $113,127,128,147-149,153,157$, 161，168，195，204，207, 209, 212, 216

Ples-Bęben Marta 12

Podgórzec Zbigniew 199, 211

Pöggeler Otto 61, 216

Pokorná Terezie 208

Polin Raymond 155

Pomian Krzysztof 45, 212

Prečan Vilmém 209, 215, 217

Przemysł Ottokar II 102

Př́íhonský František 115, 216

Puc Jan 160, 204
Rádl Emanuel 21, 81, 83, 100, 127, $128,140,141,151-154,165,166,203$, 207-209, 211, 213

Rąb Łukasz 12

Reichenbach Hans 157

Reinach Adolf 15, 163

Reinhardt Karl 37, 216

Rezek Petr 16, 52, 133, 134, 216

Ricoeur Paul 155, 181, 216.

Ritter Gerhard 100, 216

Ritter Joachim 46, 215

Ritter Martin 17, 216

Rodrigo Pierre 32, 216

Rothaker Erich 57, 210

Rorty Richard 18, 52, 216

Rousseau Jean-Jacques 122, 192

Ruin Hans 16, 218

Šabata Jaroslav 216

Šalda František Xaver 100

Sallis John 18, 216

Sartre Jean-Paul 12, 43, 149, 155, 216

Schaller Klaus 173, 179, 213

Schauer Gordon Hubert 101, 217

Schelling Wilhelm Joseph Friedrich 33

Schifferová Vĕra 109, 155, 171, 173, 205, 206, 208-210, 213.

Schiller Friedrich 114

Schleiermacher Freidrich 124

Schrödinger Erwin 157

Schuhmann Karl 123, 217

Scruton Roger 169, 217

Sepp Hans Reiner 47, 213, 217

Seifert Jaroslav 11, 183

Shore Marci 192, 193, 217

Sidorek Janusz 162, 213, 215

Siemek Marek J. 18, 212

Skalický Karel 152, 217

Škára Martin 155, 217

Skilling Harold Gordon 137, 182, 175, 217

Skovajsa Marek 82, 210

Škvorecký Josef 55, 217

Smetana Augustin 115

Smetana Bedřich 11

Sobotka Milan 173, 217 
Sokol Jan 148, 179, 217

Sokrates 7, 8, 10, 12, 17, 19, 21, 22, 36-42, 48-50, 53, 54, 64, 70, 82-84, 93, 95, 144, 145, 149, 155, 168, 180, 200-202, 207, 208, 209, 215, 216,

Sołżenicyn Aleksandr 145

Spencer Herbert 150

Spemann Hans 157

Spengler Oswald 19, 217

Spinoza Baruch 21

Srovnal Jindřich 123, 215

Srubar Ilja 9, 19, 28, 47, 203, 204, 217

Stachowski Jan 100, 214

Stahel Richard 92, 215

Stalin Józef 176, 178

Staudigl Michael 148, 210

Stoel Maxem van der 188, 191, 217

Stojka Róbert 55, 109, 209, 217

Sucharek Pavol 92, 215

Švorcová Jiřina 186

Szczepańska Elżbieta 40, 62, 204, 210

Szuster Marcin 192, 217

Tardy Vladimír 156

Tholt Pavel 109, 208, 209

Toynbee Arnold 57

Tretera Ivan 178, 217

Tucker Aviezer 102, 107, 192, 193, 217

Utitz Emil 164, 165

Vaculík Ludvík 181, 189, 190, 218

Varsik Branislav 156
Vejražka Martin 209

Veselý Jindřich 63, 218

Vetter Helmuth 164, 211

Vico Giambattista 56

Vladislav Jan (właśc. Ladislav Bambásek) 209

Vojtěch Daniel 43, 115, 205, 207, 208

Volkmann-Schluck Karl Heinz 48, 218

Voltaire (właśc. François-Marie Arouet) 192

Vorovka Karel 151

Waczków Józef 15, 212

Wajs Andrzej 30, 213

Walczewska Sławomira 159, 213

Wartenburg Paul von Yorck 57, 210

Weber Florence 136, 204

Weltsch Felix 165

Witwicki Władysław 39, 46, 72, 216

Wocial Jerzy 20, 213.

Wodziński Cezary 33, 178, 200, 205, 211

Wyrzykowski Stanisław 50, 215

Zahavi Dan 16, 218

Zajíček Pavel 183

Žižka Jan 141

Zouhar Jan 112, 120, 124, 178, 212, 215, 218

Zumr Josef 120, 178, 179, 213, 218 
Dariusz Bęben

\section{Man in the horizon of history and authenticity of Being Studies in the Philosophy of Jan Patocka}

\section{Summary}

It is extremely difficult to identify the centre of Jan Patočka's philosophy. This can be either the concept of natural world, but also subjective phenomenology or philosophy of history. I believe that the diversity of perspectives, and the motives that intermingle and cross with each other do not distort the centre of his thoughts, it is the struggle for authentic being of a human. Patočka addresses a human who fights for his soul which manifests in that he rejects the obvious, the absolute, the otherworldly, the certain.

Patočka was critical about the history of classical metaphysics (from Plato to Husserl), believing that it aimed at what is certain and objective, and finally - absolute and eternal. He contrasted it with the Socratic uncertainty and problematicity. The concept of Patočka was particularly visible in the interpretation of Plato's theory of ideas. The Czech philosopher showed a specific form of knowledge about the absolute transcendence with special relationship of human life to the entirety, including the primary reference to the non-existence. Patočka emphasized the negativity as an inherent characteristic of human freedom. The horizon of this freedom is formed by temporality and historicity.

Patočka's approach to the philosophy of history is special. One can say that the concept of the Prague philosopher went beyond the framework of the classical understanding of the philosophy of history. Patočka did not treat it as a philosophical reflection on the history especially that he did not think of any historiographical reflections: the philosophy of history is not an interpretation of what happened. According to Patočka, the history always represents the history of man. The history is an objective power that is beyond the understanding of a man. On the other hand, people may only give the meaning to their lives in the history.

The history of Europe was another important topic of Patočka. Europe is a philosophical concept. When asked what was Europe, he replied by describing and clarifying its history and forces that governed it. In his deliberations, Patočka was focusing on its formation (by asking: how has Europe become Europe?) and on what happened later and was described by him as the post-European era (why did Europe fall?). Also all that have spread between the birth and the death, what was the course of spiritual fate of Europe, was of 
importance. According to Patočka, it was the caring for soul that had made the foundation of the European heritage.

In the discussion concerning the meaning and the continuity of Czech history Patočka had to take the floor. Firstly, he referred to the history of the dispute, arguing against the opinions of Jungmann, Bolzana and, above all, of Masaryk. Secondly, in this context it is possible to take a wider look at the very concept of the Patočka's philosophy of history, looking at it from the angle of its national application, in other words: from the side of the philosophical and political responsibility of individuals in their social and political lives.

Because the philosophy of Patočka is closely associated with his life, the last part of the book includes his intellectual biography. It consists of two parts: the first one describes the meetings with philosophers who influenced the development of his views, starting from the Greek philosophy, through Husserl to the Comenius. All this variety of inspirations shows that the unity of the history of philosophy and the philosophy of history come to the fore in the philosophical achievements of Patočka. The second part addresses the philosophical (and personal) participation of Patočka in the political events that took place in Czechoslovakia. This is how the tragic synthesis of Socratic life and thinking took place.

According to Patočka, a man who wants to live in truth must not let the calm harmony of everyday life dull him, he must open to what is disturbing and mysterious - to what is left aside by life - to be able to pass from the order of the day to the mystery of the night. 


\section{Dariusz Bęben}

\section{Der Mann im Horizont der Geschichte und eigentlichen Seins Studien zur Philosophie von Jan Patocka}

\section{Zusammenfassung}

Der Mittelpunkt der Philosophie von Jan Patočka kann nur schwierig benannt werden. Das kann genauso gut das Konzept der natürlichen Welt, aber auch die asubjektive Phänomenologie oder die Geschichtsphilosophie sein. Ich denke, dass die Vielfalt von Perspektiven und Motiven, die ineinander fließen und sich miteinander kreuzen, den Kern seiner Gedanken, also den Kampf um das authentische Dasein des Menschen, nicht verzerrt. Patočka setzt sich mit einem Menschen auseinander, der sich einem Kampf um seine eigene Seele stellt. Das manifestiert sich dadurch, dass er alles, was eindeutig, absolut und alles, was jenseits der Welt liegt, was sicher ist, ablehnt.

Patočka hat die Geschichte der klassischen Metaphysik (von Plato bis Husserl) kritisch beurteilt. Er meinte, dass diese nur das Sichere und das Objektive - und im Endeffekt das Absolute und das Ewige - angestrebt hatte. Dem stellte er die sokratische Ungewissheit und Fraglichkeit gegenüber. Das Konzept von Patočka ist insbesondere bei der Auslegung der Ideenlehre von Plato erkennbar. Der tschechische Philosoph zeigt eine spezifische Form des Wissens über das absolut transzendente Dasein, in dem eine besondere Beziehung zwischen dem menschlichen Leben und dem All, darunter auch der primäre Bezug auf die Nichtdasein auftreten. Patočka betonte, dass die Negativität eine immanente Eigenschaft der menschlichen Freiheit darstellt. Der Horizont der Freiheit wird durch Vergänglichkeit und Geschichtlichkeit bestimmt.

Die Einstellung von Patočka der Geschichtsphilosophie gegenüber ist besonders. Man kann behaupten, dass das Konzept dieses Prager Philosophen den Rahmen der herkömmlich verstandenen Geschichtsphilosophie gesprengt hat. Patočka hat sie nicht als eine philosophische Reflexion über die Geschichte wahrgenommen. Umso weniger hatte er an historiografische Überlegungen geglaubt: Für ihn ist die Geschichtsphilosophie keine ausreichende Interpretation davon, was geschehen ist. Dem Tschechen zufolge kann die Geschichte seit jeher nur als Geschichte des Menschen ausgelegt werden. Die Geschichte besitzt ihre objektive Stärke, die von Menschen nicht verstanden werden kann. Andererseits können Menschen ihrem Leben Sinn nur dann geben, wenn sie in der Geschichte eingebettet sind.

Das weitere wichtige Thema bei Patočka ist die Geschichte Europas. Europa fungiert hier als ein philosophischer Begriff. Er hat die Frage danach, was Eu- 
ropa ist, beantwortet, indem er die Geschichte und die Kräfte beschrieben und erörtert hat, die Europa regieren. In seinen Ausführungen war Patočka darauf fokussiert, wie Europa entstanden ist (die gestellte Fragen: Wie wurde Europa zu Europa?) sowie darauf, was danach geschehen ist und was von dem tschechischen Philosophen als Nach-Europa-Zeitalter beschrieben worden ist (warum ist Europa zusammengebrochen?). Das Geschehen zwischen der Geburt und dem Tod, also Untersuchung des geistigen Schicksals Europas, spielt auch eine große Rolle. Patočka glaubt, dass die Seelenfürsorge einen Grundstein für das europäische Erbe bildet.

Die Stimme Patočkas konnte natürlich auch nicht bei der Diskussion über den Sinn und die Kontinuität der tschechischen Geschichte fehlen. Erstens hat er sich auf die Geschichte der Streitigkeit selbst bezogen und mit Ansichten von Jungmann, Bolzana und insbesondere von Masaryk polemisiert. Zweitens kann man in diesem Kontext das Konzept der Geschichtsphilosophie ein wenig breiter betrachten und diese in Hinsicht auf seine nationale Nützlichkeit beurteilen. Anders gesagt: Diese im Licht der philosophischen und politischen Verantwortung der Einzelperson im gesellschaftlich-politischen Leben hinterfragen.

Die Philosophie von Patočka ist sehr eng mit seinem eigenen Leben verknüpft. Aus diesem Grund beinhaltet das letzte Kapitel dieses Buches seine intellektuelle Biographie. Dieses Kapitel besteht aus zwei Teilen: Der erste Teil beschreibt seine Begegnungen mit Philosophen, die sein Gedankengut beeinflusst haben, begonnen mit griechischer Philosophie, über Husserl, mit Komenski am Ende. Diese insgesamt sehr reiche Inspiration zeigt, dass die Einheit der Philosophiegeschichte und der Geschichtsphilosophie in dem philosophischen Werk von Patočka im Vordergrund steht. Der zweite Teil befasst sich mit der philosophischen (aber auch persönlichen) Beteiligung von Patočka an politischen Ereignissen in der Tschechoslowakei. In dieser tragischen Weise ist bei ihm die sokratische Synthese des Lebens und des Denkens vollbracht worden.

Laut Patočka kann kein Mensch, der in Wahrheit leben will, sich leisten und erlauben, dass die ruhige Harmonie des Alltags ihn in eine Art Schlaf versetzt; er muss offen sein dafür, was beunruhigend und geheimnisvoll ist, also dafür, wovon sich das Leben meistens abwendet, um in die Tagesordnung nach dem Geheimnis der Nacht zu übergehen. 